\title{
The Traitor and the Stowaway: Persona Construction and the Quest for Cultural Anonymity and Cultural Relevance in the Trajectories of Bob Dylan and Leonard Cohen.
}

\section{Christophe Lebold}

\author{
Department of English and North American Studies \\ University of Strasbourg, France \\ lebold@unistra.fr
}

\begin{abstract}
While wide apart in terms of cultural heritage and creative energy, Leonard Cohen and Bob Dylan offered baby-boomers complementary figures: the (non)protest-singer as prophet and agent provocateur and the troubadour as high priest of the depths of the heart. Approaching persona as a collaborative text, I propose to analyze how Dylan and Cohen's reception (or rejection) as cultural heroes has influenced the conduct of their career and the development of their artistic gesture, leading them to constantly redefine their modes of performance. In this respect, Dylan and Cohen's trajectories can be seen as inverted images of each other: the former spends most of his career in a cultural war against his original position of hyperrelevance, trying to obliterate his own persona and regain a cultural anonymity, while the latter a poet with no rock credentials - has to struggle his way towards a position of cultural relevance and turn what was essentially perceived as a literary gesture into a rock statement. Along the way, we will be brought to reflect on personae as sites of tension between industry branding and artistic autonomy, authenticity and theatricality, pop pleasures and social significance, bringing to the fore a distinction between readerly and writerly personae.
\end{abstract}

Keywords: persona construction, songwriters, postmodern lyricism.

\section{Introduction}

With the possible exception of Bob Dylan, male singer songwriters, it seems, are somehow overlooked in popular music studies and it is easy to understand why: they're dangerous subjects.

Although ears sometimes suffer at Dylan concerts, although we did always get our fare share of theatricality in Leonard Cohen's tours, singer-songwriters are often perceived as standing outside the paradigm of fun, bodily empowerment and "rhythm and noise" that rock is associated with. The "archetypal rock artists" for Frith (1978, p.186), singer-songwriters are thought to foster a canonical approach to rock music (Shuker 2001, pp.115-119) and to engender a personal response rather than a collective one (Street 1986, p.198). The fool-hardy analyst dealing with this category of artists is therefore suspected of wanting to reinstall a cultural hierarchy, a pantheon based on value judgments: not a good move. 
Used at some point in rock history to legitimize rock music as an art form, male singer songwriters are now paying the price of their literacy in post-punk purgatory. Not unlike the more gender-study friendly female singer-songwriters, they are often presented as slightly peripheral to rock. Hence the slight tinge of irony when John Street confines Cohen and the like to adolescents' "bedsitting rooms" (where they belong?) (Street 1986, p.198), or when Middleton mentions "the hushed concentration typical of singer-songwriter concerts" (Middleton 1990, p.95).

It is true though: singer-songwriters seem to call for a critical approach based on textual analysis, a method that often evaluates songs in terms of literary complexity and disregards music as social text and collective meaning. Little is made of sound or of how the songs or the artist's personae actually reverberate in our lives. ${ }^{1}$ But, when dealing with Bob Dylan or Leonard Cohen, it's inescapable: both are endowed with what John Landau famously claimed was the staple of "art in rock": "the capacity to create a personal, almost private universe and to express it fully" (cited in Frith 1983, p.53). Both artists have created diegetic, linguistic and sonic universes that are as recognizable as William Blake's: hotels rooms in snowstorms crowded with angels and madwomen that are actually saints spell Leonard Cohen as surely as burlesque parades of cryptic winds, words and dancing fools with flutes (and boots) in mounting floods evoke mid-sixties Bob Dylan.

"There must be some way out of here", though, as Dylan sings (Dylan 2004b, 224). Their achievements as creators of literary worlds will not be our chief concern here. Our aim will be to analyze how Dylan and Cohen's reception (or rejection) as cultural heroes has influenced the conduct of their career and the development of their artistic gesture.

Being originally marketed respectively as the protest prophet of non-conformity (Dylan) and the troubadour-like High Priest of the Heart (Cohen), both artists found themselves in a triple bind: they simultaneously had to display the social relevance and authenticity connected to the folk ethos (they were popular heroes), the intensity and focus expected in high art (they were poets), and the entertainment value and sense of cool associated with pop pleasures (they were stars).

To preserve their artistic autonomy, both performers had to subvert and distort their original image, to constantly reconfigure their mode of performance and public persona. In both cases, this included artistic struggles against the audience, strategic struggles against the music industry, and discursive struggles against the critics.

But Cohen and Dylan's trajectories, as we will try to show, are inverted images of each other: while Dylan spent most of his career in a cultural war against his original position of hyper-relevance, trying to obliterate his original persona as 'mouthpiece of his generation' and regain a sense of cultural anonymity, Cohen - formerly a poet and thus a deserter from the world of high art with no rock credentials - had to struggle his way towards a position of cultural relevance in the face of mistrust and critical derision.

To explore these issues, instead of detailed analysis of lyrics or examinations of cultural contexts, ${ }^{2}$ we will try to locate the overall artistic gesture specific to each artist, his master-gesture so to speak, with special regards to their processes of persona construction.

One critical stance we are indebted to is Stephen Scobie's attention to persona as text, which he developed in his work on Cohen and Dylan, claiming that:

If [the author] is dead as authority, as source, then he is very much alive as text. Indeed we must read 'Leonard Cohen' - the figure who sits in that Los Angeles Bar, or who appears on the Tonight Show with Jay Leno [...] - very much as text, as part of the text, as part of the work, perhaps indeed as the centre of the work $(1993,11)$. 
In Alias Bob Dylan, his brilliant, post-structuralist influenced study of Dylan, Scobie $(1991,19)$ invites us to read the 'Bob Dylan text' with "as much care and intelligence as one would devote to the reading of a poem". This approach - which is reminiscent in some ways of Richard Dyer's work on "star texts" (Dyer 1998 and 2003) - will be useful in two ways: in stressing the textuality of the persona, it reminds us that a public image is something that is coherent and constructed. It thus invites a semiological approach to persona, which we'll try to develop when dealing with both artist's major postures and masks. Also, 'text' is a concept that involves processes of coding/decoding and thus we will be able to study persona construction as a dynamic, collective and playful game that involves three players: the artist, the audience and the industry.

Drawing on Scobie's hypothesis, I suggest that Dylan and Cohen transform their public personae into small works of art, fictional figurations of themselves offered to the enjoyment of the audience, ceaselessly constructed and deconstructed, in a practice which I wish to call "personal palimpsests", constant accumulation of new faces.

Dylan and Cohen's personae stand at the heart of their cultural struggle, caught as they are between industry branding and reclamation of artistic autonomy, authenticity and performance, and truthfulness of gesture and masking games.

As we proceed, we will be brought to reflect on the functions and uses of heroes in rock culture and assess the amount of pop pleasures taken in the enjoyment of a popular singer's masks and personae.

\section{'I'm glad I'm not me!'3}

In terms of cultural heritage, of favored idiom and of creative energy, Dylan and Cohen seem polar opposites: the former is from Mercury - unpredictable, gestural, in search of formless art - while the later is from Saturn - solid, full of gravitas, in love with the pleasures of form. Yet they have something in common: when they defined their basic masks and postures, they reconfigured the figure of oral poet as a cultural hero for the mass-media and provided baby-boomers with complementary figures: the prophet of non-conformity and the high priest of the heart.

While Cohen is essentially an inheritor, Dylan - it has been widely documented - is a cultural thief. ${ }^{4}$ He comes from an imagined American past where circuses, blackface minstrelsy and the blues meet folk poetry and burlesque movies. Throughout his career, he defines a poetics of betrayal and metamorphosis in ever changing masks and unstable songs. Plugged on mercurial energies, he is the son of the wind and of electricity.

From the onset of his artistic journey, his three basic assets were:

- a voice defined by its tremendous authority and its deep resonance (haunted as it was by the older voices of the blues, of Appalachian folk, and of the Bible),

- an artistic gesture that seemed radical and bold (in terms of writing, singing and performing style) in the politically progressive but artistically conservative context of the folk revival movement. As opposed to many folk artists of the time, who tended to fetishize or sentimentalize the folk tradition, Dylan indeed was always inspired by what was alien and strange in the repertoire, not by what is familiar and homely. ${ }^{5}$

- a wonderful talent for the manipulation of cultural signs and the spontaneous creation of personae. Dylan always knew that singing in public was personal theatre. His first mask is particularly well-known: a youthful proletarian hobo with a posture oscillating between the prophetic and the Chaplinesque. 
These qualities explain the tremendous impact Dylan had first on the folk scene (he was quasi-officially ordained crown-prince of the movement at the Newport Folk Festival in the summer of 1963), on America (he hit the top of the national charts and the front-pages of newspapers later that year) and eventually on world youth (in the course of early 1964). By 1965, he embodied the Zeitgeist so perfectly that it seemed he had single-handedly redefined not just the culture that had seen him emerge, but the whole of culture: everything that he wrote, did, said or wore seemed for a time to matter as some kind of definitive cultural statement. In a key passage of his study on the roots, context and resonance of the song 'Like a Rolling Stone', Greil Marcus presents 1965 Dylan as standing at the heart of Western Consciousness and turning, in quasi-Pentecostal manner, every listener into an evangelist:

\begin{abstract}
It was an incident that took place in the recording studio and was then sent out into the world with the intention of leaving the world not quite the same. [...]. In that way, the song as an event transformed its listeners into witnesses. It was up to the listeners-as-witnesses [...] to tell the story to others [...], to carry the event with them or to seek to leave it behind (Marcus 2006, pp.150-151).
\end{abstract}

Inevitably, the media - and Columbia records' marketing department - were quick to disseminate a certain number of clichés about Dylan - "poet", "prophet", "voice of his generation", "voice of the left"... - collectively creating a "Bob Dylan figure" synonymous with protest and non-conformity. That figure instantly penetrated the collective imagination and as a result, Dylan, while still in his early twenties, found himself in a position of hyper-relevance: he was considered a legitimate mouthpiece for the youth or the counter-culture at large, and everything he said was endowed with huge significance, even giving rise to (and this had not been the case for any popular artist before) a dylanian hermeneutics: dylanology.

Although it was rejected by Robert Zimmerman himself as early as 1964 in songs like "It Ain't me, Babe" (lyrics available in Dylan 2004b, p.131), this emerging protest figure was animated with a life of its own. An object of collective transference, a complex interface, that figure was used by the media to interpret the cultural crisis of the sixties; it was used by the rock scene to establish its cultural legitimacy and it was used by youths to define their values and construct a definitive cultural hero.

In the process, duplicated on album covers, on magazines and poster art, Dylan's face was turned into an easily recognizable all-purpose sign, what we casually call an "icon". But the more the image was disseminated in the public sphere, the emptier it became as a sign. This is manifest for instance in the way counter-cultural (and commercial) art seized the singer's image in the mid-to-late sixties.

A few examples of re-interpretations of Dylan's face will illustrate this point: the artwork for the cover of Crawdaddy Magazine \#23 (1969) for instance features a colorized picture of a mid-sixties Dylan inside a red halo emanating beams that seem to illuminate the world. ${ }^{6}$

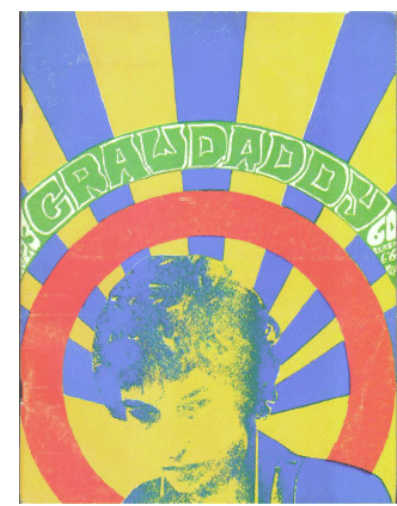

Figure1: Crawdaddy Magazine Cover (1969). 
Likewise the 1970 poster for a re-issue of D.A.Pennebaker's documentary Don't Look Back by Alan Aldrige and Harry Willock presents Dylan as an androgynous mythological animal that reconciles the male and female principle with the electric flux of his guitar - a clear vision of how the rock scene in the Aquarian Age saw itself if ever there was one. ${ }^{7}$

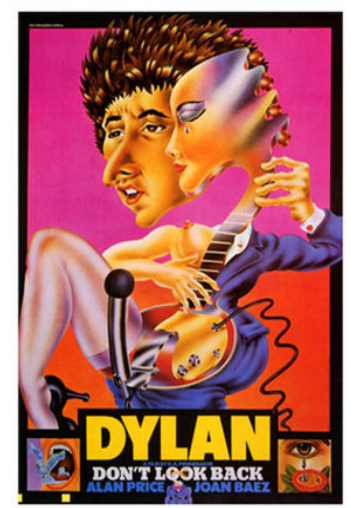

Figure 2: ‘Don’t Look Back’ Poster by Alan Alridge and Harry Willock.

The 1967 "Blowing the Mind" cover art by Martin Sharp for the British countercultural magazine $\mathrm{Oz}$ (soon turned into a popular poster) shows Dylan's gigantic head in sunglasses hovering over a psychedelic background like a hieratic Eastern divinity while a smaller black-and-white picture of Dylan seems to be imagining the whole landscape. ${ }^{8}$ From that poster's perspective, the whole universe is Dylan's dream and in psychedelic wonderland, we all partake of Dylanhood: Dylan is the equivalent of atman, the Hindu concept for the substance of the universe.

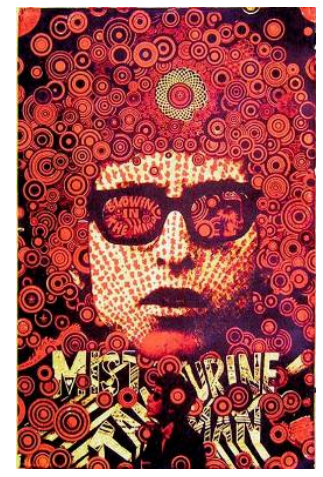

Figure 3: 'Blowing the Mind' by Martin Sharp.

With hindsight, it is plain to see how counterculture (and advertising) had turned Dylan's iconic face into an all-purpose quasi-empty sign, signifying unspecific non conformity and countercultural transcendence (in a movement of commodification and dissemination reminiscent of what happened to Ernesto Guevara's face). As the "Bob Dylan figure" was thus mythologized, it was paradoxically de-politicized, being drawn out of any specific political context.

\section{"All I do is protest. You name something l'll protest about it."”}

Now, these recuperations were very much at odds with Dylan's artistic temperament and modus operandi. Indeed, what Dylan is fundamentally concerned with as a poet and a performer is free-flowing energy and the poetry of metamorphosis, 
whether it be that of society ('The Times They are A Changin') or that of the individual ("he not busy born is buzy dying" as he sings in 'It's All Right Ma/l'm Only Dying). In love with the wild freedom and spontaneous poetry intrinsic to ambulant circuses, Barnum freak shows or anonymous folk songs, he inscribes himself in an American poetics of spontaneity and formlessness. ${ }^{10}$ It even seems that what Dylan does with songs on stage is to deconstruct them, to erase their form: he seems to seek an art that is purely gestural and he throws himself into songs the way Jackson Pollock threw color on canvas.

Such a lover and practitioner of the open-form was bound to take issue with any fixed image of himself, particularly with one constructed by the media and the actors of civil society. As he ironically mentions in the first volume of his memoirs:

\begin{abstract}
Whatever the counterculture was, I'd seen enough of it. I was sick of the way my lyrics had been extrapolated, their mimics subverted into polemics and that I had been appointed as the Big Buddha of Rebellion, High Priest of Protest, the Czar of Dissent, the Duke of Disobedience, Leader of the Freeloaders, Kaiser of Apostasy, Archbishop of Anarchy, the Big Cheese. What the hell are we talking about? Horrible titles any way you look at it. All code words for Outlaw (Dylan 2004a, 120).
\end{abstract}

Actually, Dylan organized the rest of his career as a cultural war against this protest image, a war that he declared on the media and on his audience. His strategy was threefold and included a systematic betrayal of audience and industry expectations, the adoption of struggle and resistance as his chief artistic process (including the transformation of the concert into a war waged on the audience) and a constant breaking up of his position of hyper-relevance by erasing and deconstructing the mythological "Bob Dylan" that - as he fully knows - is still haunting and cannibalizing him today.

\title{
Erasing and deconstructing Bob Dylan
}

Erasing Dylan is exactly what he does circa 1965-1966, a time when he methodically inverts all the traits that defined the early sixties protest-singer figure. In his work of that period, he does indeed retreat from the social and political realities that had concerned him at first into the sole realms of the symbolic and the imaginary.

The "message" is obfuscated: all interviews are transformed into little moments of performance art where an active war is waged against meaning, just as the lyrics of his songs get increasingly hermetic. The new Dylan likes "doorknobs", is "as happy as an ashtray", there are "frogs inside his socks", cows "speak to him", a "black Madonna" passes him by riding her "motorcycle", as does "Einstein disguised as Robin Hood" ${ }^{11}$ The message was pretty straightforward: there no longer was any message, something that Dylan has dramatized in complicity with the photographer Jerry Schatzberg in several publicity photo sessions in late 1965 whose results show (among other things) Dylan burning a bunch of keys with his cigarette lighter or blowing smoke onto a nineteen century golden-framed piece of bourgeois portraiture. ${ }^{12}$

In terms of persona construction, Dylan actively turns the heroic protest character of the early sixties into a 'puppet Dylan', wonderfully captured by Barry Feinstein's pictures of the 1966 English tour that show a motley-shirted and excessively gaunt Dylan skipping and hopping his way through the streets of England. ${ }^{13}$ The available footage of the tour (widely available on the Internet) also shows Dylan at his most uncannily puppet-like, complete with jerky movements and funny walks. This Dylan that Dylan then embodies on stage and off-stage is reminiscent of the theatre of the absurd and fits perfectly into the contemporary universes of lonesco, Beckett or the Living Theatre. In Paris, Dylan even confronted the press accompanied by a puppet and pretended to answer questions only after consulting the puppet by putting his ear close to its mouth, seeming to claim that he 
himself is a fictional character as well as a puppeteer. His face actually erased by the sunglasses and turned into a mask, Dylan becomes a quasi-anonymous countercultural Shakespearian clown.

This reconfiguration of his anonymity will be reprocessed at various stages of his career, during which his demeanor and constructed masks strive to demonstrate he is not "Bob Dylan" but an ordinary pastoral poet (in his country phase), an anonymous vaudeville performer (in his many performances with his face painted white during the Rolling Thunder Review tour of 1975, a mask that erases his individual face and ironically inverts the blackface of minstrel performers). Even today's new face is a mask, albeit a more subtle one: with his Clark Gable-style pencil moustache and his southern Stetson hat, Dylan presents himself as a singer so old that he dates from before his own era, a position that allows him to reclaim the whole experience of American popular culture. Transforming his face in this way, Dylan recovers what anthropologists have determined is the earliest known function of the mask: the embodiment of the ancestors' spirit. As the historian of art Ferino Pagden explains, ancestor masks are often used: in oral cultures to connect the group to its past. The mask is worn in rituals by a performer, who loses his identity and becomes the group's past, a position which enables him to become an intermediary or emissary to the gods (Ferino-Pagden 2009, pp. 57-60). In Dylan's case, rock rituals have replaced religious one, but the function of the face remains the same: sporting his hat and pencil moustache Dylan becomes the "great ancestor", the very embodiment of the American past, and he can thus serve as intermediary to the "great spirit" of the blues or American popular culture at large, with which it is possible be united with -through Dylan's face and sounds - for the time of the performance, a process that is wellknown to the category of fans that experiences and sees Dylan as an 'authentic' expression of the cultural past of America.

\section{Bob Dylan's Art of War}

However, in Dylan's art, posture is denounced as imposture and relevance and pertinence are replaced by impertinence. While the artist's early concerts worked towards the construction of a community of spirits between audience and singer, his electric concerts of 1965 and 1966 were essentially an outrage to his audience informed by Antonin Artaud's aesthetics of cruelty that Dylan seems to import into rock. ${ }^{14}$ The public was subjected to rituals of amplified electric noise and to Dylan's howling voice and screeching harmonica in an atmosphere often close to rioting.

That violent confrontational rapport with his audience will become Dylan's trademark and he will redefine it often, as when he wages an ideological war on his future former fans by preaching born-again Christianity and the coming of the apocalypse in his gospel tour of 1980, or even in today's 'never-ending tour', where an unsmiling Dylan nightly sabotages part of his material, deconstructs the songs so as to make them unrecognizable and utterly formless while still assaulting his audience with decibels, sometimes to the point of unbearableness. This is part and parcel of Dylan's artistic gesture, what I call "the Judas complex", the need not to deliver, the absolute urge to betray the expectancies of the audience.

Of course, Dylan uses other strategies to deconstruct his hyper-relevance, such as the purposeful publication of mediocre albums (think of the perversely entitled Self Portrait (1970) or Dylan (1973) for instance), or the sheer proliferation of material another way to de-dramatize and deflate the importance of the work: this is just the $43^{\text {rd }}$ album and the second this year: how could it be the new tables of the Law? The publication of an album of Christmas songs in late 2009 (after having featured in commercials for Chevrolet and women's lingerie in the previous years) might just be another move in that direction: becoming omnipresent, becoming the all-purpose voice 
of America, the channel through which the American experience is carried across, a postmodern Walt Whitman.

But whatever one makes of abundance or occasional mediocrity, what is clear is that, for the audience, an engagement with Dylan's work is an engagement with a struggle. He struggles against the audience and we are made to struggle against what we project onto Dylan and accept the fleeting nature of the songs, the performance and the personae.

\section{"Depressing? Moi?"}

As opposed to Dylan, Leonard Cohen is not a thief but an inheritor: he received at birth three thousand years of Judaism, the whole of the poetic tradition in English and a natural talent for depth. Following his fundamentally rabbinical disposition, his gesture is to reveal the hidden meaning of the world and the profundities of the human heart. In his songs, he reclaims the pleasures and sensuousness of gravity (in every sense of that term).

His trajectory seems a mirrored refection of Dylan's. A Canadian poet and novelist with no rock credentials, he had to struggle hard to establish credibility in the rock field, while being perceived as defecting from high-art circles (at the cost of a severe critical backlash in the literary field). From the onset of his rock career, he was a traitor and a stowaway, a position he has thematized a lot in his work.

Originally though, Cohen's status as troubadour was bankable and made for success on a very large scale in Europe and to a more modest extent in America, where he was more of a singer's singer. The archetypal singer-songwriter, producing finely crafted, adult-oriented songs that had depth and fostered meditative listening, Leonard Cohen was indeed marketed by Columbia records as "the poet of rock" (the actual inscription on ticket stubs and publicity posters for the 1976 European tour).

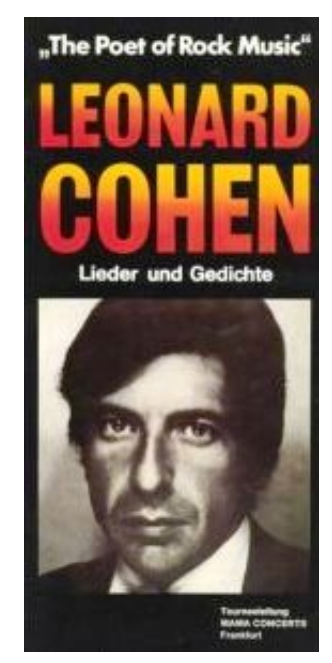

Figure 4: Poster for the 1976 European Tour.

But over the course of the seventies, as the rock scene was taken over by guitar heroes and macho posturing and later by the do-it-yourself oppositional ethos of punk, this original image as highly skilled troubadour backfired. Cohen was increasingly considered as basically incompatible with the rock ethos - insoluble in rock - and, as he admits himself, by the late seventies "my name was used essentially for comic relief" (quoted in Sheppard, p.129). The English musical press was particularly scathing and treated Cohen with derision, disseminating countless monikers like 'Laughing Len', 'Prince of the Bedsits', 'Grand Master of Melancholia', or phrases like 'Low-key self- 
pity' or 'music to slit your writs by.' 'Depressing? Who? Me?' (Turner, 1974): titles of articles set the mood and the content rubs the prejudice in as does Evans Allens who starts his NME review of Cohen's album Songs of Love and Hate with these words: "What a depressing guy this Cohen is!" and ends it with "if you want to be depressed, this is for you!" (Evans 1971). Cohen himself never tires of quoting the classic (mis)reporting of his 1970 Isle of Wight Performance in the Melody Maker: "Leonard Cohen is an old bore who should just return to Canada which he never should have left to begin with" (cited in Nadel, p.178).

While this is largely a case of journalist wit and cynicism, there are larger issues of discursive power and symbolical authority at stake.

As Simon Frith explains (1983, p.10) rock critics were then considered as figures in their own right, the intellectuals of rock, the agents of its weekly theorization in rock magazines. In Frith's words, they were the "mythologists" of rock and as such, it seems they naturally tended to dislike articulate artists who seemed to intrude on their territory, the author of "Suzanne" being among the most articulate (with the likes of Lou Reed, another major voice often rejected as verbose and pretentious). But more largely still, making Cohen irrelevant, presenting him - and, I claim, very wrongly so - as outside the paradigm of "rock" reveals the fundamental aporia of rock ideology. As countless cultural analysts and popular music scholars have put forth, rock culture can be seen in some cases as mainstream posing as underground, teenage-hedonism posing as radical and seeking for the cultural legitimacy of avant-garde movements. In the context of the society of the spectacle, rock music could very well be seen as a nicely-packaged theatre of subversion, advertised to consumers as 'authentic', 'vital' and 'rebellious'. Rock ideology thus imposes a double bind on artists, as is evident in the monikers Cohen has been tagged with: to be entertainers and perform subversiveness at the same time.

In this context, Cohen became in effect a cultural guerrilla who had to fight a discursive and artistic war against the rock establishment and, pretty soon, a strategic war against the industry that was ready to drop him. To survive commercially, he had to turn what was essentially perceived as a literary gesture into a rock statement. This meant two things: displaying his radicality in a more obvious way and developing the theatricality of his art; finding a way to re-define his persona as non-troubadour and turn his position as outsider/stowaway and traitor to his advantage.

This 'cultural redemption' follows the course of Cohen's career: four stages which correspond to four masks: the melancholy poet, the lecherous ladies' man, the über-cool crooner and the high priest of the heart. I would like now to examine each stage in turn in connection with the issues of radicality and symbolic prestige that concern us here.

\section{Cold as a new razor blade: reclaiming the gloom}

In the early seventies famously Cohen "stepped into an avalanche". It covered up his soul, he tells us ('Avalanche'). With albums like Songs of Love and Hate, and the accompanying tours (documented by the Bird on a Wire documentary of 1974) the artist developed a radicality of starkness in form (two guitars, a bass and minimal melodies) and darkness in content. He explored topics such as suicide and failure. His art of lament was crystal-clear, precise and elegant; it treated feelings like facts of the heart to be analyzed with surgical precision and radically de-sentimentalized the love song.

With hindsight, this proto-cold wave phase (that would later inspire groups like Dead Can Dance or Sisters of Mercy or people like Nick Cave) sounds very sophisticated and refreshing, and much more radical and subversive than many rock acts of the decade, all the more so as it is certainly not devoid of grim humor and deadpan jokes - a typical example being Cohen's reproduction of a razor blade above 
each poem of his 1972 collection The Energy of Slaves in response to the accusations of his songs being "music to slit your wrist by". Years of self-deprecating humor were to follow.

\section{"Deep-down inside I got a rock and roll heart."}

In the face of declining album sales and much derision from the musical press, Cohen changed his strategy after 1974 and decided to fully embrace the rock ethos. $\mathrm{He}$ de-poeticized his stage persona (he was even seen wearing a leather jacket), amplified the sound and, in concert, rocked up the tempos of many songs. The reintrepretation of his late sixties song 'The Butcher' for the 1976 European tour being a classic example: he turns the original blues rhythm into galloping rockabilly and carries the song to a full climactic ending that has him screaming away the chorus.

This approach reached its climax with the singer's ill-fated collaboration with Phil Spector for the album Death of a Ladies' Man (Sony-Columbia, 1977), an artistic suicide of sorts which the rock critic Paul Nelson described in Rolling Stone as a "doowop nightmare"(Nelson, 1978). Cohen screams out lyrics such as "Don't go home with your hard-on, it will only drive you insane." As it turns out, the way the poet's gravitas is deformed by the Wagnerian schmaltz of Spector's arrangements is not uninteresting, as are Cohen's investigations of the vulgarity of consumer culture, of gender relations as war, of the shallowness of sex and of his own status as a rock star ("just another faithful woman's favorite singer millionaire, the patron-saint of envy and the grocer of despair/ working for the Yankee dollar", as he describes himself in 'Field Commander Cohen'). Though stimulating, this is not Cohen's most loved period, and the 1976 single 'Do I have to dance all night?' seems to encapsulate the artist's dilemma:

I'm Forty-One, the moon is full,

You make love very well.

You touch me like I touch myself,

I like you Mademoiselle,

But Do I have to dance all night?

But do I have to dance all night?

Oh, tell me, Bird of Paradise,

Do I have to Dance all night?

Or in unpoetic words: is this rock and roll zoo really integral to what he has to say?

Critics at any rate were unconvinced, as was clear on the cover of the then forward-thinking French magazine Rock\&Folk, whose December 1977 cover featured a drawing of Cohen clutching an electric guitar, frozen in a swaying Elvis pose, beneath the title 'COHEN ROCKER?'

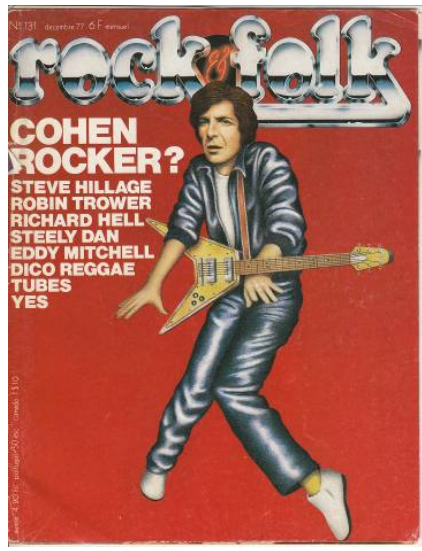

Figure 5: Rock and Folk magazine Cover, December 1977.

I@J vol.1, no.2 (2010) http://www.iaspmjournal.net 
Columbia records evidently shared these reservations, and its artistic director Walter Yetnikof decided not to distribute Cohen's subsequent albums in the United States, famously explaining to Cohen: "Leonard, we know you're great, but we don't know if you're any good" (cited in Nadel, 238).

\section{Banana Casanova}

A third act to Cohen's cultural war on the hegemonic system of mainstream pop opens with the album I'm your Man (Sony-Columbia, 1988), a record followed by a highly successful world tour that signaled the singer's definitive entry in the rock pantheon and jumpstarted his critical and commercial rehabilitation. The title can be read as a challenge, as a declaration of war on the industry of mass culture, just as the song 'First we take Manhattan' is a manifesto for his rock ambitions - namely to hit the American market - dilated on a Napoleonic scale. The elliptic mystery laden lyrics are actually quite explicit when heard in this context:

They sentenced me to twenty years of boredom

For trying to change the system from within

I'm coming now, I'm coming to reward them

First we take Manhattan, then we take Berlin.

I'm guided by the signals in the heaven

I'm guided by these birthmarks on my skin

I'm guided by the beauty of our weapons

First we take Manhattan, then we take Berlin.

What the song is is a five-minute scenario for the revenge tragedy that will have him humiliate the Industry that had rejected him. With a new machine-driven synthetic sound (computerized poly-rhythmic pop inspired by the Pet Shop Boys), and the wonderful picture by Sharon Weitz of the singer as a Mafioso looking rock star eating a banana on the album cover, Cohen re-invents himself as the absolute hipster. This new persona - which I propose to call "Banana Casanaova" - is a fully postmodern doublecoded figure, endowed with the best of both worlds: the cool value of rock culture and the depth of high art.

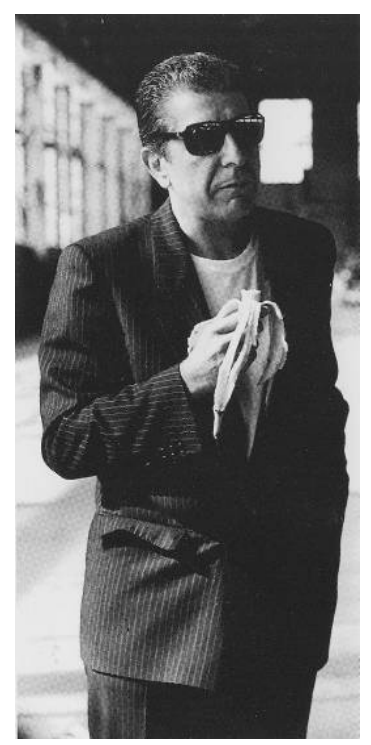

Figure 6: Picture by Sharon Weitz used for the cover art of l'm Your Man 
Space forbids to expand on the very complex and playful banana symbolism at stake in this very iconic and nonetheless self-deprecating image: let us just signal its mock-heroic tone and indicate that there definitely is a tension here between the dandy and monkey, the dramatized death of a ladies' man and the celebration of the seducers' craft. Indeed, the banana is obviously phallic and what we see is a professed seducer - seducing is a very large component of Cohen's 'star-text' - symbolically eating his own weapon! At the same time, eating a banana is an act that requires a certain delicacy: one has to carefully 'undress' the fruit before consuming it, exactly as a seducer operates with a woman, so we also see Casanova eating a banana. Of course, there are also cultural references illustrated here, the least of which is not to the Velvet Underground: Cohen is here consuming Warhol's iconic banana, seeming to be half-ironically reclaiming the band's cool, radical and sexy heritage of avant-garde rock, after "twenty years of boredom", the time span that separates I'm Your Man from The Velvet Underground and Nico!

Facing us here with his übercool sunglasses is a self-professed cultural double agent, a spy of poetry in the realm of mass art, and an agent of cool in the realm of poetry, a perfect incarnation of the traitor as prince of subversion that was theorized by post-structural thinker Gilles Deleuze (Deleuze and Parnet, pp.54-57), able to subvert each cultural fields with the weapon of the other. Guided by the beauty of the weapons he found in Yeats, Dante and the Bible, he will now have his fare share of hit singles and TV appearances.

\section{The high priest as crooner, the crooner as high priest}

Within the framework of what could be called 'a mystique of kitsch', the most recent phase in Cohen's career combines the radicality of the first stage with the postmodern humor of the third. With a voice that is now deep enough to simultaneously assert the seductions of predatory masculinity and the spiritual realities of exile, brokenness and fall (it is indeed a voice that is in exile, that is fallen, that is forever rejected from the forbidden territory of the high-pitched) Cohen re-invents the singer as beautiful loser and the crooner as high priest. The singer of love becomes the ultimate spiritual authority while the love-song is equated with the art of the biblical psalmist.

Cohen himself claims on stage that the concerts of the 2008-2010 world tour are turned into 'spiritual experiments.' Indeed, they generate intense moments of grace, reverence (and stand-up comedy) as the songs become more and more what they always were: spiritual weapons, instruments of war meant to break open our hearts with the might of beauty. The musical textures and structures, the tensions (between spoken word and melody, between minimalism and kitsch, between the iconic gravity of Cohen's voice and the angelic quality of the female sopranos) transport us into metaphysical landscapes of sound and actually dramatize for the ear the data of Cohen's spiritual vision, letting us hear the irretrievable failure of man and the unyielding mercy of God, the marriage of gravity and grace and of heaven and the earth.

As the many awards the singer received in the past fifteen years and the coverage of present concert tour have made clear, ${ }^{15}$ Cohen has made a full critical recovery, something he achieved as he increasingly accepted the theatricality of his art and the need to be an entertainer. As he stated twenty-five years earlier to Zig-Zag magazine:

Whatever you do, you should be an entertainer first. If you're going to present yourself to people, they have to be entertained. Their imagination has to be engaged and they have to enter into the vortex of imagination and relaxation and suspense that is involved in entertainment (Pike, 1974). 
One way Cohen the performer engages the imagination of his audience is with an elaborate theatre of the self. "I'll wear a mask for you" is what he sings in 'I'm your Man' (Sony-Columbia, 1988), as much a declaration to his audience that to the lover in the lyrics. In concert, he does indeed change masks from song to song: he is in turn lecherous sinner, wandering Jew, hopeless monk, Zen master, high priest and even each spectator's guardian angel. This art of masks creates a playful and seductive rapport with the audience and re-enforces the feeling of intimacy we have with the singer, but, like a show of puppets, it is also very dramatic in itself, it is stimulating, rich in suspense and meaning. Cohen's masks are tools for us to explore our own relationship to the sacred and to the futilities and transient glories of the theatre of the self.

\section{Conclusions}

As we have seen, Leonard Cohen and Bob Dylan's artistic trajectories run an inverted course: Dylan gradually erases himself into paradoxical anonymity while remaining a haunting and quasi omnipresent figure while Cohen increasingly embraces the rock scene and constructs personae that are more and more efficient theatrically. Each trajectory involves a cultural struggle won by the artist: Dylan has become undecipherable and synonymous with the enigma of American popular culture, and Cohen has been recognized for the important and relevant artist that he is.

In both cases we have been brought to note that the artist's public persona, as a site of cultural and artistic tension, was a collaborative and unsteady construct where the artist's original postures interact with music industry processes of branding, the fans' projections and re-inventions of the figure and the artist's deconstructive gesture.

When Richard Dyer (Dyer 2004, p.IX) calls for "a way of understanding the social significance of stars which fully respects the way they function as media-texts", he requires first that we acknowledge the textual nature of a star's persona: personae are texts, signs systems that have a dynamic inner coherence and function on the basis of a coding/decoding activity. As such, personas, just like texts, may generate various types of engagement, from passive consumption to active and playful interpretative engagement. In $S / Z$, the French post-structuralist thinker Roland Barthes (Bathes 1970, p.10) introduces a distinction between textes lisibles and textes scriptibles, two concepts which are often translated as "readerly texts" or "writerly texts". The formers are texts that are simply consumed by readers, leaving the writer in full charge of the creation of meaning: those texts bring pleasure. Writerly texts, on the other hand demand our active hermeneutic participation: they convey bliss (jouissance) and empower us.

I claim that artists like Bob Dylan and Leonard Cohen, with their masking games, their practice of the 'personal palimpsest', do more than simply advertise themselves or construct mythologies: they offer their personae to the audience as 'writerly' texts that call for our playful and hermeneutic engagement.

This art of masks is playful. it is also subversive, transforming us as it does from passive regressive consumers of masks and identities to active decoders engaged with the mysteries of identity construction. Enjoying and interpreting Dylan and Cohen's theatre of masks invites us into a dynamic and problematised vision of identity that can help us overcome the fixed ideas we have about ourselves and the world.

But pop star's personae do not resonate with the individual fan only. At least not when they strike the collective imagination, as is the case for the two figures we have considered. Richard Dyer explains the collective impact a 'star-text' can have with the concept of 'reconciliation of contradiction': 
Stars frequently speak to a dominant contradiction in social life - experienced as conflicting demands, contrary expectations, irreconciliable but equally held values in such as way as they appear to reconcile them (Dyer, 1991, p.225).

Embodying and subsuming social contradictions would be how 'star-texts' bring meaning into our daily lives. Does that apply to the artists under scrutiny? It seems indeed that both figures carry a built-in contradiction. Dylan thus expresses America's contradictory relation to the past, standing as he does between cultural amnesia (he is a ghost of the past, trapped in the American past) and constant re-invention of himself as "forever young": a trickster spirit of independence and contrariness that teaches the mutability of things and the importance of being subversive. Cohen likewise is a paradoxical star: crooner and high priest, melancholy and humorous, religious and sexy: he stands as a figure that helps us reconcile our inscription in the postmodern age of irony with our irretrievable thirst for depth. Both, with many other singersongwriters, reconfigure the oral poet for the mass-media age.

\section{Notes}

1. The great literary critic Christopher Ricks' study of Dylan, Dylan's Visions of Sin (Ricks, 2003) is the perfect example of that type of approach. These 528 pages of analysis of lyrics (at times brilliant, at times just verbose) were published under a title that promises more than it delivers: no synthetic vision of Dylan's overall artistic gesture emerges other than his being a great manipulator of rhymes. Rick's frame of reference is surprising: T.S.Eliot is referenced 41 times, Keats 20 times, Tennyson 21 , but no mention is ever made of any bluesman. Strange bedfellows indeed for Bobby Zimmerman!

2. As was brilliantly done, in two complementary ways by Michael Gray (Gray, 1999) and Greil Marcus (Marcus 1997 and 2005).

3. Dylan's exclamation after reading about himself in a music paper in D.A. Pennebaker's documentary Don't Look Back.

4. An excellent study of sources, influences and cultural contexts is Michael Gray's Song and Dance Man. For a recontextualisation of Dylan in the context of the cannibalistic art of the blackface minstrelsy, one might wish to consult Sean Wilentz's enlightening article "American Recording: On Love and Theft and the Minstrel Boy" (cf. Wilentz 2004).

5. The singer famously said about traditional folk music: "Folk music is the only music where it isn't simple. [...] It's never been simple: it's weird. [...] All those songs about roses growing out of people's brains and lovers who are really geese and swans that turn into angels they're not going to die."(quoted in Marcus 1997, p.113)

6. The image is widely available on the Internet.

7. Easy to find on the web, the image is reproduced in A Century of Pop (Gregory 1998, p.146).

8. Again a well-known and widely disseminated image, reproduced for instance in Sixties. Années Utopies (Gervereau and Mellor 1996, p.197).

9. London, press conference, May 1965.

10. This search for informality could even be considered as the defining trait of the American spirit. Where Europe stands for propriety, hierarchy and explicit structures, the American cultural experience seems to go for formlessness: in the cult of an unregulated free market, the triumph of the first-name basis in interpersonal relationships, the dream of a classless society and of course, the quest for open form in art, whether in the gestural art of Pollock or the improvisation of jazz...

11. The first two quotes are from 1966 interviews with the Melody Maker and the New Musical Express, cited respectively by C.P. Lee (Lee 2006, p.47) and Clinton Heylin (Heylin 1996, p.102); the following 
quotes are, in sequence from the lyrics of "On the Road Again", "Bob Dylan's 115 Dream", "Gates of Eden" and "Desolation Row" (Dylan 2004b, respectively p.147, p.148, p.155 and p.182).

12. The pictures in question have since become iconic pop pictures of the sixties. They have recently been reproduced in many magazines, but one might want to consult Jerry Schatzberg's own highquality publication of them in his excellent coffee-table book Thin Wild Mercury: Touching Dylan's Edge (see bibliography).

13. Fine reproductions are available in Feinstein's book, Real Moments. The famous pictures taken in Liverpool are particularly haunting (Feinstein 2008, pp.52-61).

14. Though it is not inconceivable, I am not suggesting that Dylan had actually read Artaud's books. But biographical evidence suggests that, as a member of the Greenwich Village Bohemia, who attended off Broadway performances with Suze Rotolo and been on friendly terms with Julian Beck and Judith Malina, founders of the hugely Artaud-influenced Living Theatre group (Henthoff 2004, 22), he was bound at least to be familiar with the avant-garde theories of Brecht, Artaud and Dada and the two latter's common insistence on ritual violence and sacrifice.

15. Among those, we could cite a Crystal Globe Award by CBS records for I'm Your Man, an induction into the Canadian Hall of Fame in 1991, an appointment to the Order of Canada the same year; the Juno Award for Best Male Vocalist and a Governor's General's Award for the performing Arts in 1993, the induction into the Canadian Songwriters Hall of Fame in 2006 and into the Rock and Roll Hall of Fame in 2007.

\section{References}

Barthes, Roland. 1970. S/Z, Seuil, Paris.

Cohen, Leonard. 1974. The Energy of Slaves / L'Energie des Esclaves (bilingual edition), 10/18, Paris.

Deleuze Gilles and Parnet Claire. 1996. Dialogues, Flammarion, Paris.

Dyer, Richard. 1991. 'A Star is Born and the Construction of Authenticity' in Gedhill Christine ed, Stardom: Industry of Desire, Routledge, London.

Dyer, Richard. 1998. Stars, BFI Publishing, London, $2^{\text {nd }}$ (revised) edition.

Dyer, Richard. 2003. Heavenly Bodies: Film Stars and Society, Routledge, London, $2^{\text {nd }}$ (revised) edition.

Dylan, Bob. 2004a. Chronicles (Volume 1), Simon and Schusters, New York.

Dylan, Bob. 2004b. Lyrics 1962-2001, Simon and Schusters, New York.

Evans, Allan. 1971. 'Leonard Cohen: Songs of Love and Hate', New Musical Express, 22 May.

Feinstein Barry. 2008. Real Moments. Bob Dylan by Barry Feinstein, Omnibus Press, London.

Frith, Simon. 1978. The Sociology of Rock, Constable, London.

Frith, Simon. 1983. Sound Effects: Youth, Leisure and the Politics of Rock n'Roll, Constable, London.

Ferino-Pagden Sylvia. 2009. 'Die Maske der Erinnerung' in Ferino-Pagden (ed) Wir Sind Maske, Kunsthistoriches Museum Wien, Wien, pp.57-64. 
Gervereau, Laurent and Mellor, David. 1996. Les Sixties. Années Utopies, Somogy éditions d'art, Paris.

Gray, Michael. 1999. Song and Dance Man III: the Art of Bob Dylan, Continuum Publishing, New York and London, $3^{\text {rd }}$ edition.

Gregory, Hugh. 1998. A Century of Pop, Hamelyn, London.

Henthoff, Nat. 2004. 'That Crakin', Shakin', Breakin' Sounds' reproduced in Hedin ed., Studio A: The Bob Dylan Reader, Norton, New York, pp.22-39 [1964].

Heylin, Clinton. 1996. Bob Dylan: A Life in Stolen Moments. Day by Day 1941-1995, Music Sales Limited, London.

Lee, C.P. 2004. Like the Night (Revisited). Bob Dylan and the Road to the Manchester Free Trade Hall, Helter Skelter Publishing, London.

Marcus, Greil. 1997. Invisible Republic. Bob Dylan's Basement Tapes, Picador, New York.

Marcus, Greil. 2006. Like a Rolling Stone: Bob Dylan at the Crossroads, Public Affairs: New York.

Middleton, Richard. 1990. Studying Popular Music, Open University Press, Milton Keys.

Nadel Ira, 1996. Various Positions. A Life of Leonard Cohen, Bloomsbury, London.

Nelson, Paul. 1978. 'Leonard Cohen's Doo-wop Nightmare', Rolling Stone, 9 February < http://www.webheights.net/speakingcohen/rs20978.htm>

Pike, Robin. 1974. 'September fifteen, 1974', Zig-Zag Magazine, October, <http://www.webheights.net/speakingcohen/zigzag.htm>

Ricks, Christopher. 2003. Dylan's Visions of Sin, Viking, London.

Rock\&Folk, 1977, (issue n`131, december), Editions du Kiosque, Paris.

Schatzberg, Jerry. 2005. Thin Wild Mercury: Touching Dylan's Edge, Genesis Publication, London.

Scobie, Stephen. 1991. Alias Bob Dylan, Red Deer College Press, Alberta.

Scobie, Stephen. 1993. 'The Counterfeiter Begs Forgiveness: Leonard Cohen and Leonard Cohen' in Stephen Scobie (ed), The Proceedings of the Leonard Cohen Conference, Canadian Poetry Studies Doc Review, 1993, vol 33, pp.7-21.

Sheppard, David. 2000. Leonard Cohen, Thunder Mouth's Press ("Kill your Idols" series), New York.

Shuker, Roy. 2001. Understanding Popular Music, Routledge, London. $2^{\text {nd }}$ edition.

Street, John. 1986. Rebel Rock: The Politics of Popular Music, Blackwell, Oxford.

Turner, Steve. 1974. 'Depressing? Who? Me?' New Musical Express, 29 June <http:www. /rocksbackpages/87/leonard-cohen-depressing-who-me.html >

Wayne, Hampton. 1986. Guerrilla Minstrels: John Lennon, Joe Hill, Woody Guthrie and Bob Dylan, University of Tennessee Press, Knoxville.

Wilentz, Sean. 2004. 'American Recordings: On Love and Theft and the Minstrel Boy' in Hedin, Benjamin ed., Studio A. The Bob Dylan Reader, Norton, New York, pp.263274.

\section{Discography}

Cohen, Leonard. 1971. Songs of Love and Hate, CBS (69004), March.

Cohen, Leonard. 1976. 'Do I Have to Dance All Night? / The Butcher', CBS (4431).

Cohen, Leonard. 1977. Death of a Ladies' Man, CBS (86042), November. 
Cohen, Leonard. 1988. I'm Your Man, CBS (460-642-1), February.

Dylan, Bob. 1964. 'It Ain't Me, Babe', Another Side of Bob Dylan, CDCBS 32034 (current issue), August.

Dylan, Bob. 1965. Bringing it All Back Home, CDCBS 32344 (current issue), May.

Dylan, Bob. 1965. Highway 61 Revisited, CDCBS 62527 (current issue), August.

Dylan, Bob. 1970. Self-Portrait, CDCBS 4601122 (current issue), July. 